\title{
Otorragia en una paciente pediátrica atendida de urgencias
}

\author{
Bullido Gómez de las Heras E. ${ }^{1}$, Santillán Sánchez M.², Villoria López A. ${ }^{3}$, Muñoz Sánchez M. ${ }^{1}$ \\ Sanid. mil. 2014; 70 (4): 307-308; ISSN: 1887-8571
}

Niña de 10 años que presentaba otalgia y otorrea en el oído derecho desde hacía varios días. Estos síntomas progresaron hasta sufrir, durante la noche, una otorragia franca. Sus familiares, alarmados, solicitaron de madrugada atención en la Urgencia hospitalaria.

La paciente pertenecía a una clase social con riesgo de exclusión y bajos recursos económicos. Sus familiares referían una historia clínica sin antecedentes personales de relevancia, salvo la recurrencia de procesos infecciosos de vías respiratorias altas asociados a respiración nasal dificultosa y episodios de otitis de repetición. Nunca habían acudido al especialista en ORL. La paciente había presentado otorreas de manera intermitente, que fueron tratadas con antibióticos por vía oral, la secreción según nos describían era de moderada a escasa cuantía y a veces con mal olor.

La pediatra de guardia explora a la paciente, y al realizar la otoscopia del oído derecho aprecia algo extraño e inquietante, por lo que avisó al ORL alertado.

Tras la primera valoración, fue explorada en la de zona de consultas externas de ORL, donde con el consentimiento de sus familiares, se documentó el caso.

Las siguientes imágenes pertenecen a la exploración inicial de la paciente, realizadas con un endoscopio rígido de oído de $30^{\circ}$ y $2,6 \mathrm{~m}$, gracias al cual pudo grabarse un vídeo del que se seleccionaron estas imágenes.

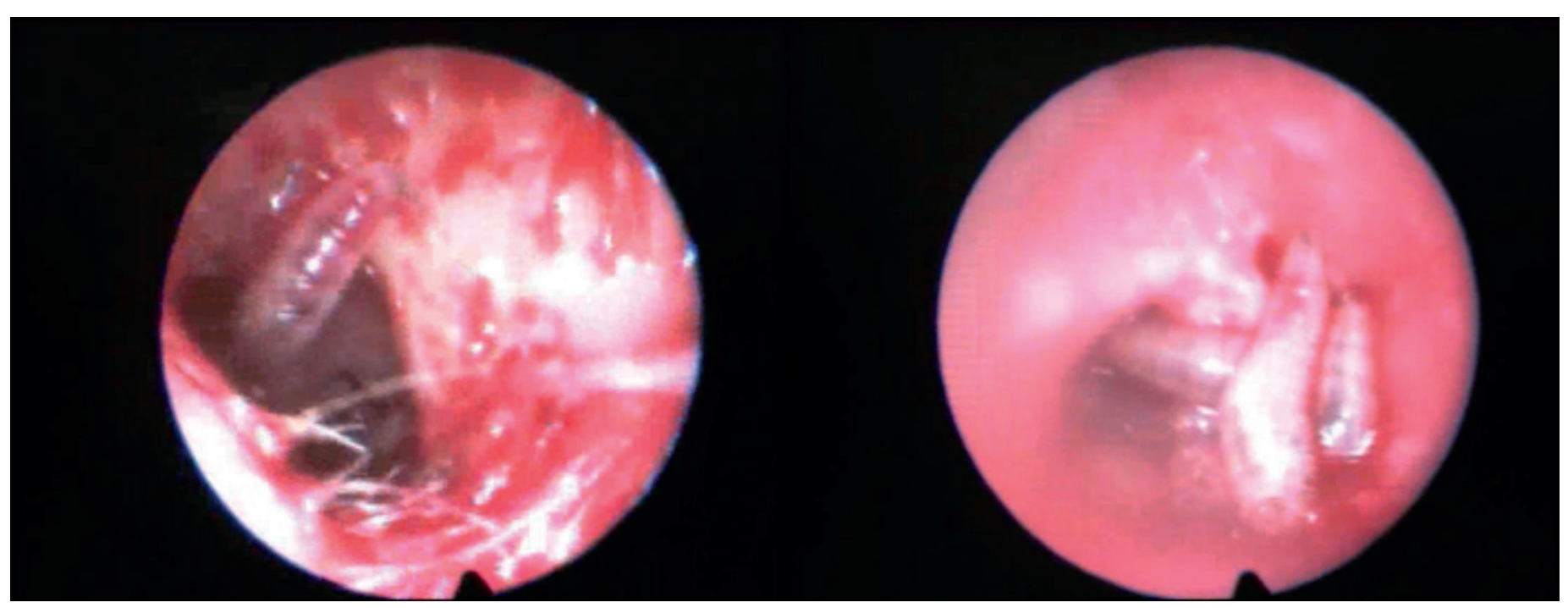

Figuras 1 y 2. Imágenes obtenidas en la exploración de la paciente con un endoscopio rígido de oído.

\footnotetext{
${ }^{1}$ Tcol. Médico. Servicio de ORL.

2 Tte. Médico. Servicio de ORL.

${ }^{3}$ Tte. Médico. Alumno de Formación Especializada en Medicina Familiar y Comunitaria.

Hospital Central de la Defensa Gómez Ulla. Madrid. España.
}

Recibido: 16 de julio de 2014

Aceptado: 4 de septiembre de 2014 


\section{Diagnóstico: Miasis por larvas de mosca del género sarcophaga}

El término miasis fue propuesto por Hope (1840) ${ }^{1}$, para definir la infestación originada por las larvas de dípteros ciclorrafos o muscoides en el hombre o animales, de quienes se nutren en forma parásita de tejidos vivos o muertos. Según las formas clínicas se dividen en miasis cutáneas y cavitarias. Son frecuentes en países tropicales, aunque en nuestro país eran frecuentes en ambientes rurales y ganaderos ${ }^{2,3}$.

Son varias especies de mosca las que pueden estar implicadas, y estas varían según los países. Las miasis pueden ser producidas por larvas biontófagas o necrobiontófagas. Las primeras invaden tejidos vivos o cavidades naturales y son parásitos obligados; las segundas colonizan lesiones preexistentes y son parásitos accidentales ${ }^{4,5}$.

En nuestro caso, el díptero causante es del tipo de las necrobiontófagas. Esta mosca libera directamente las larvas de su abdomen, ya eclosionadas, que comienzan a alimentarse de los tejidos inflamados o en descomposición ${ }^{2}$.

A nuestra paciente se le instilaron gotas de lidocaína al 1\%, pues al sospechar la existencia de perforación timpánica no se consideró conveniente usar lavados con sustancias más agresivas, y se extrajeron 12 larvas (cortas, de aspecto blanquecino y con lo que parecía la zona cefálica de un color más oscuro) que fueron enviadas al servicio de microbiología para su correcta filiación. Posteriormente en Microbiología fueron filiadas como larvas de mosca del género sarcophaga.

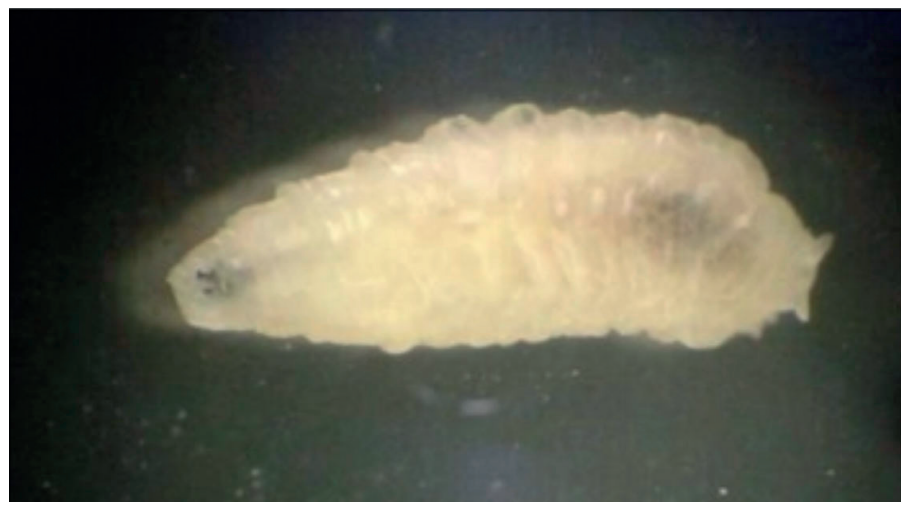

Figura 3. Una de las larvas extraídas.
La exploración posterior de la enferma objetivó una otitis media crónica colesteatomatosa, causada a su vez por problemas tubáricos crónicos y mala respiración por hipertrofia adenoidea. Dicha otitis, con supuración persistente y destrucción de tejidos óticos, favoreció la infestación parasitaria.

El tratamiento es la eliminación de las larvas y el tratamiento adecuado de las lesiones supurativas. En casos no tratados, las larvas producen gran destrucción tisular, y en casos extremos pueden penetrar incluso a la cavidad encefálica causando meningoencefalitis y la muerte ${ }^{6,7}$.

\section{BIBLIOGRAFÍA}

1. Beaver P, Jung R, Cupp E. Miasis. Parasitología clínica. 2 ed. Barcelona: Salvat; 1986.

2. Tourrella X. Miasis cutánea. Piel. 2002;17(7):300-309.

3. Cruz S. El estudio de la miasis en España durante los últimos cien años. Ars. Pharmaceutica. 2000;41(1):19-26.

4. Konkol K, Longfield R, Powers N, Mehr Z. Wound myiasis caused by Cochliomyia hominivorax. Clin Infect Dis. 1992;14: 366.

5. Elgart M. Flies and myiasis. DermatolClin. 1990;8(2):237-244.

6. Uriarte F. Ell S. "Doctor, there are maggots in my nose". Case report.JRSM. 1997;90(1):634-635.

7. Beckendorf R, Klot S, Stephen A. Nasal myiasis in an intensive care unit linked to hospital-wide house infestation. Arch Intern Med. 2002;162(6):638-640.

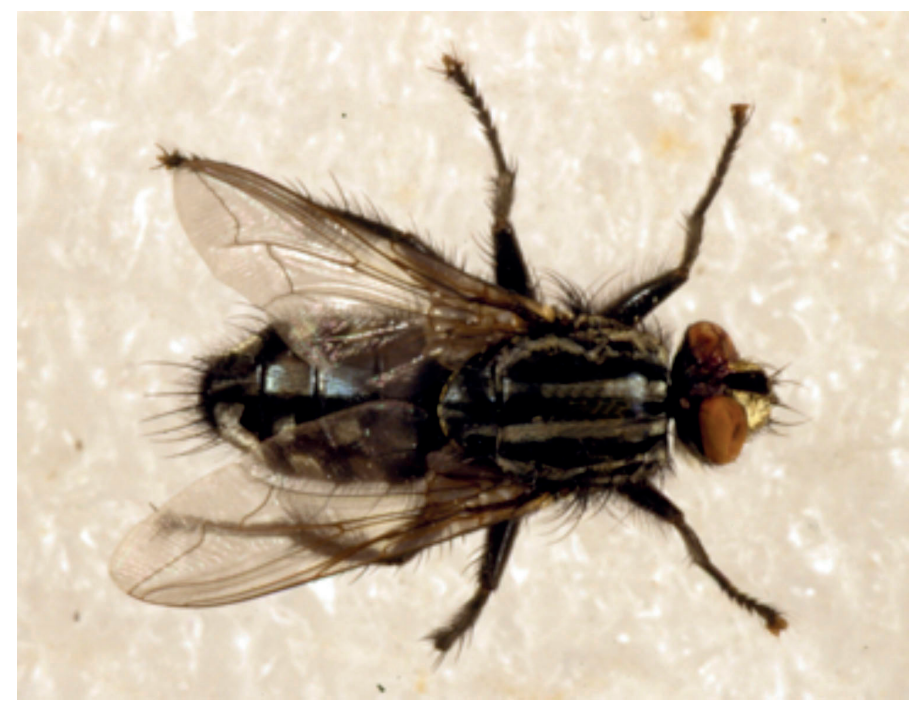

Figura 4. Sarcofaga carnaria. Reproducción con autorización de su autor Dr. Fernandez Rubio. 